Поставлено та проаналізовано розв'язок оптимізаційної задачі про мінімум часу руху безпілотного безекіпажного апарату (ББА). Встановлено зв'язок між проекціями вектору швидкості, як умовою розв'язку задачі про мінімум часу переміщення, запропоновано будувати алгоритм корегування параметрів оптимальної траєкторіі. Продемонстровано, якщо на траєкторії обрано як маситаб величину «с» між поперечними похідними від модуля вектора швидкості за двома ортогональними напрямами, а також забезпечено дію сил, які з тим же масштабом «с» зв'язують другі похідні від координат за цими напрямами, то така траєкторія мінімізує загальний час руху. Розділення рухів утворює можливості керування на підставі відеозображень за умов дотримання обмежень на величину маситабу «с» та накладає обмеження на роботу двигунів - приводів рушіїв. Встановлено, що калібрування рушїв дозволяе визначити константу «с».

Сформовано керуючі впливи: сили та моменти для гідродинамічної моделі ББА. Запропоновано представлення керуючих впливів через число обертів валу рушія - пропелера. Представлено керуючі впливи через функцію належності та мінімальне і максимальне паспортне число обертів валу пропелеру рушія.

Введено нові якісні поняття, що задано функцією належності: ивидкості обертання валу рушія до таких значень, які могуть бути реалізовані двигуном $\mu_{i}\left(n_{s} / n_{\text {max }}\right)$; сили упору, яка забезпечує прискорений рух ББА за паспортом $\mu_{s x}(x, t)$; підймної сили, яка забезпечуватиме надлишок підйомної сили $\mu_{s y}\left(x^{*}\right)$; швидкості обертання валу рушія, яка забезпечить механічну потужність при економічному споживанні електричної енергії.

Промодельовано процес вибору швидкості обертання валу рушіїв піӘ иас просторового руху безпілотного, безекіпажного апарату з урахуванням впливу таких якісних факторів. Продемонстровано спрощення прощесу вибору відносної ивидкості обертання валу рушія під час керування ББА. Показано на числових прикладах незалежність і стійкість величини розрозрахованної функцї̈ належності перетину та обраної відносної частоти обертання валів рушїв від вибору кутів орієнтацї вісей рушіїв

Ключові слова: оптимальна трєкторія, розділення рухів, керуючі впливи, нечіткі множини, трансформація операцій

$\square$

口-

\title{
TRANSFORMATION OF OPERATIONS WITH FUZZY SETS FOR SOLVING THE PROBLEMS ON OPTIMAL MOTION OF CREWLESS UNMANNED VEHICLES
}

\author{
A. Tru nov \\ Doctor of Technical Science, \\ Professor, Head of Department \\ Department of Automation \\ and computer-integrated \\ technologies \\ Petro Mohyla Black Sea \\ National University \\ 68 Desantnykiv str., 10 , \\ Mykolaiv, Ukraine, 54003 \\ E-mail: trunovalexandr@gmail.com
}

\section{Introduction}

Development of airborne [1-3] and submarine [4-6] crewless and unmanned vehicles (CUV) creates preconditions for development of drone transformers capable to perform tasks in air, on water surface and under water [7]. Such a variety of design types and working conditions requires intellectual restructuring of model design forms [8]. However, significant growth of the design process labor stimulates search for new approaches which would lead to rejection of the conventional paradigm of «description» and its replacement with the paradigm of «prescription» [9]. As shown in works $[10,11]$, it is expedient to implement such a paradigm in accordance with theoretical foundations of coordination [12] and apparatus of the fuzzy set theory. However, classical apparatus of the solid body dynamics is unsuitable for conditions of fuzzily set moments and path of motion. As a result, such analysis apparatuses are incompatible.
The problem of propagation of a light ray in a plane is one of classical examples of variational statement and solution of the problems of undetermined optimization of the motion path and its parameters [13]. To solve such nonlinear problems by a quasi-linearization method, an assumption was made that the velocity vector module is proportional to the $y$ coordinate value. Practical realization of the latter assumption is complicated by limited capabilities of drive motors [6]. There are generally known models describing motion of underwater drones [8,14-17]. Such models are used for synthesis of control actions. Analysis of structure of mathematical deterministic models of underwater and airborne drones shows that their motion models also reduce to a system of six nonlinear second-order differential equations while magnitudes of Archimedean forces, resistance, coefficients of attached masses and resistances are different [8]. However, despite this similarity, the main unresolved problems consist in solution of the system of nonlinear equations 
or an approximate reduction to a recurrent sequence of analytic expressions and formation of a fuzzy control action in presence of fuzzy actions and parameters.

This study relevance is determined by the necessity of a joint application of the classical apparatus of mathematical analysis which uses operations of substantive, total and partial derivatives and an apparatus of fuzzy sets, non-compatible with it, with intersection and integration operations.

\section{Literature review and problem statement}

Effectiveness of the phenomenon of co-ordination of actions in manifestations of self-organization of pack animals and groups of people is increasingly in-depth studied and transferred to the sphere of goal achievement, even in realization with the help of inanimate man-made systems [18]. Today, this principle is increasingly being used in construction of heterogeneous dual-purpose networks and determination of technical and technological parameters [18]. Crewless and unmanned vehicles of airborne, ground-borne, seaborne and underwater functioning are examples of its application [18]. In particular, it should be expected that introduction of theoretical foundations of coordination [10] as an all-embracing procedure, together with such modern tools [12] as adequacy, efficiency, vector indicator and intellectualized development in the Taylor series will open up new opportunities [12]. As a result, we will radically change our imagination of the functions which are impossible according to the present-day attitudes and an imagination of new, unexpected applications that will be revealed tomorrow [12]. The study results showing functioning of stereovision and laser odometry onboard helicopters operated in zones that are dead zones for the GPS form the basis and prerequisites for such conclusions and expectations [19]. Airborne micro vehicles controlled based on real-time video transmission is another example of such achievements [20]. A low-cost navigation system for quadracopters which was demonstrated, e.g. in [21] is a striking example of further development. Other important examples which also create conditions necessary for development include simultaneous formation and memorization of flight path and terrain mapping [22]. The latter also allows for its use as a platform for robotic studies and education [23]. At the same time, it is increasingly recommended to use localization and complementary control systems [24]. Such means as infra-red control of mobile robots used in flexibly reorganized production processes are offered [25] for drone positioning in such systems. As shown in [26], introduction of uncertainties and application of the fuzzy set theory methods and decision making can simplify path construction and implement motion control. Combination of the method of direct relative orientation [27] and the method of determining the extreme angle [28] with Kalman filtration of information flows [29] is equally effective. The dual median filtering method is also promising for implementation of navigation based on analysis of optical image streams [30]. The methods based on construction of algorithms of active positioning using video camera image streams (which in turn are based on a multiagent approximation) were further developed in [31]. Realizability of such algorithms depends to a large extent on improvement of quality and security of encoding processes [32], decoding of video frames and efficiency of presentation compression by means of the matrix algebra operations [33].
Besides, realizability of such navigation systems determines stability of wireless communication between mobile agents of cyber-physical systems [34]. The latter is largely ensured due to development of a hardware-oriented software for architectures of fast encoding-decoding [35].

Thus, uncertainty as a major obstacle and negative feature will undoubtedly prevail in the near future as the main unresolved problem because of such level of technical solutions. Development and implementation of fuzzy systems like the examples of successful applications of expert and decision-making support systems in marine technologies demonstrate potential opportunities [36]. Even though the latter is accompanied by an unconditional transition from homogeneous networks to neural networks with fractional mechanisms of structure generation [37], the problems of uncertainty and the complications introducing discontinuities of the time derivative of the input values do not become exhausted. Simultaneously with fuzzy regulators, it is necessary to introduce mobile control of discrete levels along with self-testing [38]. A special role in this will be given to the neuron-fuzzy observer. The work project [39] is an exemplary prototype of its implementation and which will also require narrowing of libraries of fuzzy analytic computer models for operations with fuzzy asymmetric numbers [40]. Simplicity of software development based on introduction of fuzzy multiple regulators and practical control of acceleration and lifting force of such drones were demonstrated in [41]. However, despite the overall efficiency of fuzzy multiple control of one vehicle, solution of the problem of nonlinear dynamics remains the main unresolved problem for control of a group of vehicles, especially when they are working in a rank [18]. This solution, notwithstanding development of analytical tools [42] and the analytical method of recurrent approximation having ever proved efficiency for various technical and biological systems [43] is hindered by non-analyticity of membership functions as is confirmed in [44, 45]. Combination of advantages of two paradigms of which the first is based on a fuzzy multiple approach and the second on an analytic representation of information flows [12] is a law-governed logically grounded problem [46]. Development of the mentioned line of designing systems for controlling mobile collective cyber-structures with the use of special calibration tools will become effective [47].

However, joint implementation of analytic and fuzzy set methods encounters non-analyticity and non-differentiation of membership functions. Besides, application is complicated namely by the form of merge and intersection operations in working out solution of equations and equation systems by analytical methods [41].

\section{The aim and objectives of the study}

This study objective is enhancing efficiency of the mathematical apparatus of operations with fuzzy sets which will provide analytical formation of the magnitude of control action on the basis of optimal choice of a nonlinear model path, task and external perturbations with taking into account uncertainty.

To achieve the goal, the following tasks had to be solved:

- to construct an algorithm for correcting parameters of an optimal path;

- to form control actions in conditions of existing hydrodynamic model of drone; 
- to introduce new operations with fuzzy sets in a form of operators resulting in images forming continuous functions that admit operations of the classical mathematical analysis including differentiation.

\section{Optimization of the motion path}

Minimization of the time taken for travel between two given points will be presented in a three-dimensional space as one of the optimization problems (Fig. 1) as follows:

$$
\min _{f(x, y, z)} J(x, y, z, t)=\min _{f(x, y, z)} \int_{x_{0}}^{x_{1}} \frac{\sqrt{1+y^{\prime 2}+z^{\prime 2}}}{v(x, y, z, t)} \mathrm{d} x .
$$

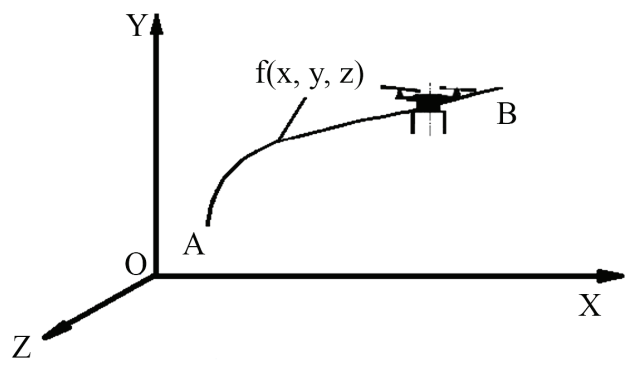

Fig. 1. Diagram of optimal CUV motion path

The Euler equation for a parametric task of motion along $O Y$ and $O Z$ axes for this problem will be reduced to the differential equation:

$$
\begin{aligned}
& \frac{\partial}{\partial y}\left[\frac{\sqrt{1+y^{\prime 2}+z^{\prime 2}}}{v(x, y, z)}\right]+\frac{\partial}{\partial z}\left[\frac{\sqrt{1+y^{\prime 2}+z^{\prime 2}}}{v(x, y, z)}\right]- \\
& -\frac{d}{d x}\left\{\frac{\partial}{\partial y^{\prime}}\left[\frac{\sqrt{1+y^{\prime 2}+z^{\prime 2}}}{v(x, y, z)}\right]+\frac{\partial}{\partial z^{\prime}}\left[\frac{\sqrt{1+y^{\prime 2}+z^{\prime 2}}}{v(x, y, z)}\right]\right\}=0
\end{aligned}
$$

or to an equation system which will take the following form after differentiation and algebraic transformations:

$$
\left\{\begin{array}{l}
\frac{1}{v(x, y, z)} \frac{\partial v(x, y)}{\partial y}+\frac{y^{\prime \prime}}{\left(1+y^{\prime 2}+z^{\prime 2}\right)}=0 \\
\frac{1}{v(x, y, z)} \frac{\partial v(x, y)}{\partial z}+\frac{z^{\prime \prime}}{\left(1+y^{\prime 2}+z^{\prime 2}\right)}=0
\end{array}\right.
$$

which in turn is equivalent to

$$
\frac{y^{\prime \prime}}{\frac{\partial v(x, y, z)}{\partial y}}-\frac{z^{\prime \prime}}{\frac{\partial v(x, y, z)}{\partial z}}=0 \text {. }
$$

It should be noted that division of motion into two mutually orthogonal uniformly accelerated motions in two mutually orthogonal planes is ensured if:

$$
\frac{\partial v(x, y, z)}{\partial y}=c \frac{\partial v(x, y, z)}{\partial z}
$$

where $c$ is an arbitrary function independent neither of $x$ coordinate nor the time which will conventionally be called the $c$ constant. Under these conditions, it follows from (3) that $y^{\prime \prime}=c z^{\prime \prime}$. The latter simplifies understanding of its physical content as a scale of accelerations in $Y$ and $Z$ axes. In addition, this result shows that if a connection between two transverse derivatives of the velocity vector module in two orthogonal directions as a scale of magnitude $« c »$ and effect of the forces that connect other derivatives of coordinates in these directions with a scale of the same magnitude $« c »$ are ensured in the path, then such path minimizes total travel time.

Thus, a transition was made that has reduced the number of variables to three while removing an explicit dependence on time but providing a minimum time when moving to a new position. The latter will allow us to use the video stream images only according to analysis of the terrain features [19] with taking no account of time in accordance with practical requirements [20].

Parameters should be adjusted using the $c$ constant chosen during design with taking into account the diagram of switching motors when maneuvering, the angle of inclination of propeller axles and the equations of constraints formed from (3). It is experimentally refined at the stage of running-in tests by calibrating spatial motion of the CUV and the equilibrium conditions described in detail, e. g. in [14-17].

\section{Formation of control actions}

to complement the transformed model of the vehicle motion

It was proved in [14-17] that thrust of one propeller takes the form:

$$
\bar{R}_{i}^{y}=C_{T} \rho n^{2} d^{4}\left(\frac{\bar{\omega}}{\omega}\right)
$$

where $C_{T}$ is the thrust factor; $\omega, n, d$ are angular velocity, rotational frequency and propeller diameter, respectively. The thrust factor depends on design features of the propeller itself, its step and the flow striking angle. The propeller characteristics are significantly improved by the use of a nose cap. The total thrust:

$$
\bar{R}^{y}=\sum_{i=1}^{N} \bar{R}_{i}^{y}
$$

The total moment determined by the propeller thrust:

$$
\bar{M}=\sum_{i=1}^{N} \bar{r}_{i} \times \bar{R}_{i}^{y}
$$

where $\bar{r}_{i}$ is the radius vector that defines position of the force application point relative to the center of the connected coordinate system. The latter is equivalent to the moment created by different rotation speeds of pairs of diametrically opposed propellers:

$$
\bar{M}=\sum_{i=1}^{N} C_{T} \rho n_{i}^{2} d^{4} \bar{r}_{i} \times\left(\frac{\bar{\omega}_{i}}{\omega_{i}}\right) .
$$

Control forces are created by motors, elevators, roll-pitch systems, stern cap, etc. The calculation algorithms are well described in [3-8] and are not the subject of this study.

The control forces and moments generated by propellers can be calculated from formulas (4)-(6) taking into 
account resulting angles of roll and pitch and equations of motion [14] or as recurrent sequences [8].

\section{Formation of additional operations with membership functions and their properties}

Examples of application of fuzzy rules to control of airborne crewless vehicles with four propellers have been demonstrated in [41]. At the same time, the choice of discrete values of membership functions in accordance with dynamic properties of vehicles and external influences remains an unresolved problem. Besides, formation of the membership functions themselves and their application in calculation of optimal effects is complicated because they are discontinuous and analytic functions. It is such a discrete representation being at first sight a simplification that leads to nonanalytical conclusions and growth of the volume of rules formed and requires correction in formation of different types of rules [32]. The latter justifies expediency of introducing a new set of elementary operations with fuzzy sets.

In connection with the above, introduce three operations with fuzzy sets.

Assume that the normal fuzzy sets $A$ and $B$ are set by analytic membership functions $\mu_{A}(x)$ and $\mu_{B}(x)$ in the normalized space of real numbers in the range from 0 to 1 , i. e. $x \in[0,1]$.

Enter the operation of complement.

Definition 1. An operation denoted by inversion sign $\mu_{A D}(x)$ and calculated as $\mu_{A D}(x)=1-\mu_{A}(x)$ is called the complement of the defined fuzzy set $A$ and the membership function $\mu_{A}(x)$ of which is given in a numerical set in a normed space of real numbers in the interval $x \in[0,1]$.

Enter the transformed union operation.

Definition 2. An operation conditionally denoted as $\mu_{T A \cup B}(x)$ which is a complement to the algebraic product of complements $\mu_{A}(x)$ and $\mu_{B}(x)$ is called the transformed union of the fuzzy sets $A$ and $B$ set by membership functions $\mu_{A}(x)$ and $\mu_{B}(x)$ in the universal number set $x$, in the normed space of real numbers in the range $x \in[0,1]$. It can be denoted by the inversion of $\mu_{A D}(x) \cdot \mu_{B D}(x)$, or calculated as $\mu_{T A \cup B}(x)=$ $=1-\mu_{A D}(x) \cdot \mu_{B D}(x)$.

Theorem 1. If two normal fuzzy sets are set in the interval of existence of a numerical set for which membership functions are specified analytically, then the complement to the algebraic product constructed for inversions has a lower limit which is the largest value selected from values of the membership functions.

Proving. As is known by definition for normal sets, application of the complement operation at the point $x \in[0,1]$ gives a segment from the ordinate of the value of the membership function to one which is $0 \leq \mu_{A D}(x) \leq 1,0 \leq \mu_{B D}(x) \leq 1$. Then, if $\mu_{A}\left(x^{*}\right) \geq \mu_{B}\left(x^{*}\right)$ at an arbitrary point $x^{*}$, then $\mu_{A D}\left(x^{*}\right) \leq \mu_{B D}\left(x^{*}\right)$ and $\mu_{A D}\left(x^{*}\right) \cdot \mu_{B D}\left(x^{*}\right) \leq \mu_{B D}\left(x^{*}\right)$. In the opposite case, if $\mu_{A}\left(x^{*}\right) \leq \mu_{B}\left(x^{*}\right)$ at an arbitrary point $x^{*}$, then $\mu_{A D}\left(x^{*}\right) \geq \mu_{B D}\left(x^{*}\right)$ and $\mu_{A D}\left(x^{*}\right) \cdot \mu_{B D}\left(x^{*}\right) \leq \mu_{A D}\left(x^{*}\right)$. Thus, the segment equal to the product of complements is smaller than the smaller value in both cases and its supplement will then be greater than the greater of two values of the membership function at that point. Write the latter as:

$$
\begin{aligned}
& \mu_{T A \cup B}(x)=1-\mu_{A D}(x) \cdot \mu_{B D}(x)= \\
& =\mu_{A}(x)+\mu_{B}(x)-\mu_{A}(x) \cdot \mu_{B}(x) .
\end{aligned}
$$

Let us introduce the transformed operation of intersection.
Definition 3. An operation which is conventionally denoted by $\mu_{T A \cap B}(x)$ and which is an algebraic product of $\mu_{A}(x)$ and $\mu_{B}(x)$ or which is calculated as $\mu_{T A \cap B}(x)=\mu_{A}(x) \cdot \mu_{B}(x)$ is called the transformed intersection of fuzzy sets $A$ and $B$ defined and specified as $\mu_{A}(x)$ and $\mu_{B}(x)$ in the numerical set $x$ in the normed space of real numbers in the interval of $x \in[0,1]$.

Theorem 2. If two normal fuzzy sets are specified in the interval of existence of a numerical set for which membership functions are specified analytically, then the smallest value is the upper limit of the product $\mu_{T A \cap B}(x)$.

Proving. Prove that the conventional operation of intersection yields the result that is the upper limit for the introduced operation by definition 3. By conventional definition of the intersection operation,

$$
\mu_{A \cap B}(x)=\mu_{A}(x) \cap \mu_{B}(x)=\min \left[\mu_{A}(x) ; \mu_{B}(x)\right],
$$

then if $\mu_{A}\left(x^{*}\right) \leq \mu_{B}\left(x^{*}\right)$ at an arbitrary point $x^{*}$, then:

$$
\min \left[\mu_{A}\left(x^{*}\right) ; \mu_{B}\left(x^{*}\right)\right]=\mu_{A}\left(x^{*}\right) .
$$

By the introduced definition,

$$
\mu_{T A \cap B}\left(x^{*}\right)=\mu_{A}\left(x^{*}\right) \cdot \mu_{B}\left(x^{*}\right) .
$$

From which always in the conditions of normality of fuzzy sets, since:

$\mu_{B}\left(x^{*}\right) \leq 1$,

then

$$
\mu_{T A \cap B}\left(x^{*}\right)=\mu_{A}\left(x^{*}\right) \cdot \mu_{B}\left(x^{*}\right) \leq \mu_{A}\left(x^{*}\right)=\mu_{A}\left(x^{*}\right) \cap \mu_{B}\left(x^{*}\right) .
$$

Since in the case when $\mu_{B}\left(x^{*}\right) \leq \mu_{A}\left(x^{*}\right)$ at an arbitrary point $x^{*}$, the second multiplier of the product is less than or equal to one, the product is less than the least value, that is:

$$
\mu_{T A \cap B}\left(x^{*}\right)=\mu_{A}\left(x^{*}\right) \cdot \mu_{B}\left(x^{*}\right) \leq \mu_{B}\left(x^{*}\right)=\mu_{A}\left(x^{*}\right) \cap \mu_{B}\left(x^{*}\right) .
$$

Thus, if analytic membership functions are applied, then operations with them form analytic membership functions as well. In addition, the intersection operation is defined as the upper limit of the operation by its new definition and if the normalization operation is additionally applied,

$$
\mu_{T A \cap B}\left(x^{*}\right)=\mu_{A}\left(x^{*}\right) \cdot \mu_{B}\left(x^{*}\right) / \sup \left(\mu_{A}\left(x^{*}\right) \cdot \mu_{B}\left(x^{*}\right)\right),
$$

then the set will be normal.

\section{Simulation of choice of the propeller axle rotation speed during the CUV motion and discussion of the results obtained}

A quadrocopter contains four motors, so to realize control of such a vehicle, windings of all four motors should be powered with amplified voltages $\mathrm{U}_{i}$ simultaneously coordinated by the microcontroller [41]. Since the minimum and maximum angular velocities are known as ratings for all motors, it is advisable to use four input parameters (acceleration, speed, displacement and lifting power) and four output parameters (speed of rotation of all four propellers). The propeller diameter is chosen according to the nominal axle rotation speed, 
$n$, which develops power $N$ of the first propeller provided that the lifting force $R$ and the weight $m g$ are equal. The second propeller axle rotates in an opposite direction with the same (by modulus) speed. The plane of the third and fourth motor axles is oriented at an angle $\Theta$ varying from $60^{\circ}$ to $90^{\circ}$ and the angle of inclination to the vertical plane, $X O Y$, is fixed $\left(\Psi=35.3125^{\circ}\right)$. For these notations, the $c$ constant will be determined as follows:

$$
\begin{aligned}
& c=\frac{y^{\prime \prime}}{z^{\prime \prime}}=\frac{\frac{d^{2} y}{d x^{2}}}{\frac{d^{2} z}{d x^{2}}}=\frac{\frac{d^{2} y}{d t^{2}} m}{\frac{d^{2} z}{d t^{2}} m}= \\
& =\frac{R+2 R \sin \psi \cos \theta}{2 R \sin \theta}=\frac{1+2 \sin \psi \cos \theta}{2 \sin \theta},
\end{aligned}
$$

and its value will belong to the interval of $c \in[0.5,2]$ at conditions and values of the $\Psi \in\left[0^{\circ}, 35.312^{\circ}\right]$, $\Theta \in\left[30^{\circ}, 90^{\circ}\right]$ angles.

To simulate choice of the propeller axle rotation speed during the CUV motion, define the concept of membership functions.

Definition 4. The membership function the propeller axle rotation speed to the range of values that can be realized by this motor has the form:

$$
\mu_{i}\left(x^{*}\right)=\left(x_{i}^{*}-n_{i \min }\right) /\left(n_{i \max }-n_{i \min }\right) .
$$

Definition 5. The membership function of the propeller axle rotation speed to the range of values that provide accelerated motion of the vehicle with mass $m$ at acceleration $a_{x}$ in the direction of the $X$ axis has the form: $\mu_{s x}\left(x^{*}, t\right)=m a_{x} / R_{x}$.

Definition 6. The membership function of the propeller axle rotation speed to the range of values that will ensure an equilibrium value of the lift force, $R_{y}$, will look like $\mu_{s y}\left(x^{*}\right)=1-R_{y} / m g$.

Definition 7. The membership function of the propeller shaft rotation speed to the range of values that will provide mechanical power $N$ for economical consumption of electric energy İ $\mathrm{U}^{\circ}$ has the form: $\mu_{s n y}\left(x^{*}\right)=\mathrm{N} / \mathrm{IU}^{\mathrm{I}}$.

Data about CUV are given in Table 1 and influence of membership functions on the choice of the propeller axle rotation speed during the CUV motion is given in Table 2.

Columns 2-6 of Table 2 contain data on relative frequency of rotation and membership functions calculated from definitions $4-7$ :

- belonging of the propeller axle rotation speed to the values that can be realized by the motor, $\mu_{i}\left(n_{s} / n_{\max }\right)$;

- thrust which provides accelerated motion of the CUV according to ratings, $\mu_{s x}\left(x^{*}, t\right)$;

- lifting force which provides an excess of lifting force, $\mu_{s y}\left(x^{*}\right)$;

- the propeller axle rotation speed which provides mechanical power at an economic consumption of electric energy.

Column 7 of Table 2 contains values of the membership function, $\mu_{n}\left(n_{s} / n_{\max }\right)$ calculated by definition 3 which makes it possible to find the best value of the membership function $\mu_{n}\left(n_{s} / n_{\max }\right)=0.2114$ and relative velocity $n_{s} / n_{\max }=0.9$. These values simultaneously satisfy the demand for advantage according to the indicated four signs (marked in bold). Such results undoubtedly demonstrate advantages of the new intersection operation.

For analysis of influence of the $c$ constant at various values of inclination angles, $\Theta$ and $\Psi$, of motor shafts, analogical calculations were performed. Their results are generalized in Table 3.

Table 1

Characteristics of the CUV

\begin{tabular}{|c|c|c|c|c|c|c|}
\hline No. & $\begin{array}{c}\text { Mass, } \\
m, \mathrm{~kg}\end{array}$ & $\begin{array}{c}\text { Propeller } \\
\text { diameter } \\
d, \mathrm{~m}\end{array}$ & $\begin{array}{c}\text { Minimum } \\
\text { angle speed } \\
\omega_{\min }, \mathrm{rad} / \mathrm{s}\end{array}$ & $\begin{array}{c}\text { Maximum } \\
\text { angle speed } \\
\omega_{\max }, \mathrm{rad} / \mathrm{s}\end{array}$ & $\begin{array}{c}\text { Rotor iner- } \\
\text { tia moment } \\
J, \mathrm{kgm}^{2}\end{array}$ & $\begin{array}{c}\text { Power } \\
\mathrm{N}, \mathrm{W}\end{array}$ \\
\hline 1 & 3.2 & 0.2 & 100 & 300 & $1.2 \cdot 10^{-4}$ & 50 \\
\hline
\end{tabular}

Table 2

Influence of the membership functions on the choice of the propeller axle rotation speed during the CUV motion

\begin{tabular}{|c|c|c|c|c|c|c|}
\hline \multirow{2}{*}{$s$} & \multicolumn{5}{|c|}{$c=2$} \\
\cline { 2 - 7 } & $n_{s} / n_{\max }$ & $\mu_{i}\left(n_{s} / n_{\max }\right)$ & $\mu_{s x}\left(x^{*}, t\right)$ & $\mu_{s y}\left(x^{*}\right)$ & $\mu_{s \eta y}\left(x^{*}\right)$ & $\mu_{n}\left(n_{s} / n_{\max }\right)$ \\
\hline 1 & 0.55 & 0 & 0.891403594 & 0 & 0.3 & 0 \\
\hline 2 & 0.6 & 0.07496252 & 0.932203799 & 0 & 0.33 & 0 \\
\hline 3 & 0.65 & 0.14992504 & 0.960259111 & 0 & 0.43 & 0 \\
\hline 4 & 0.7 & 0.22488756 & 0.978548858 & 0 & 0.6 & 0 \\
\hline 5 & 0.75 & 0.29985007 & 0.989655121 & 0.125 & 0.7 & 0.026 \\
\hline 6 & 0.8 & 0.37481259 & 0.995762737 & 0.28 & 0.88 & 0.092 \\
\hline 7 & 0.85 & 0.44977511 & 0.998659304 & 0.445 & 0.89 & 0.1779 \\
\hline 8 & $\mathbf{0 . 9}$ & $\mathbf{0 . 5 2 4 7 3 7 6 3}$ & $\mathbf{0 . 9 9 9 7 3 5 1 7 1}$ & $\mathbf{0 . 6 2}$ & $\mathbf{0 . 6 5}$ & $\mathbf{0 . 2 1 1 4}$ \\
\hline 9 & 0.95 & 0.59970015 & 0.999983448 & 0.805 & 0.35 & 0.169 \\
\hline 10 & 1 & 0.67466267 & 1 & 1 & 0.2 & 0.1349 \\
\hline
\end{tabular}

Table 3

Influence of design parameters of propellers on speed of rotation of their axles during the CUV motion

\begin{tabular}{|c|c|c|c|c|c|}
\hline No. & $\Theta$, deg. & $\Psi$, deg. & $c$ & $\mu_{n}\left(n_{s} / n_{\max }\right)$ & $n_{s} / n_{\max }$ \\
\hline 1 & 90 & 35.313 & 0.495284 & 0.2896 & 0.895 \\
\hline 2 & 70 & 35.313 & 0.738054 & 0.2896 & 0.895 \\
\hline 3 & 60 & 35.313 & 0.906597 & 0.2895 & 0.895 \\
\hline 4 & 40 & 35.313 & 1.461445 & 0.2894 & 0.895 \\
\hline 5 & 30 & 35.313 & 1.994753 & 0.2893 & 0.895 \\
\hline 6 & 90 & 25.313 & 0.496515 & 0.2896 & 0.895 \\
\hline 7 & 70 & 25.313 & 0.684171 & 0.2896 & 0.895 \\
\hline 8 & 60 & 25.313 & 0.820499 & 0.2895 & 0.895 \\
\hline 9 & 40 & 25.313 & 1.28279 & 0.2894 & 0.895 \\
\hline 10 & 30 & 25.313 & 1.734821 & 0.2894 & 0.895 \\
\hline 11 & 71 & 32.05 & $\mathbf{0 . 7 1 9 6 9 3}$ & 0.2896 & 0.895 \\
\hline 12 & 40 & 32.05 & $\mathbf{1 . 4 1 0 4 6 1}$ & 0.2894 & 0.895 \\
\hline
\end{tabular}


As the data in Table 3 show, values of the membership function and relative velocity practically do not vary and are independent of the magnitude of the $c$ constant. In their turn, design constraints imposed on variation of the $\Theta$ and $\Psi$ angles enable narrowing of the range of choosing design values of the constant $c \in[0.71,1.41]$. The latter reduces deviation of the $\Theta$ and $\Psi$ angles during maneuvers and thus improves shooting conditions for the camera. As it was demonstrated by practical application of operations introduced by definitions $1-3$, analyticity of operator expressions in conditions of analyticity of membership functions themselves allows simplification of the algorithm for calculating relative frequency. This is especially true in the problems of finding optimal time and formation of the motion path or as a solution of the strategic problem of optimization [12]. Thus, practical possibility of simultaneous application of the theory of fuzzy sets and classical methods of analysis of problems of nonlinear dynamics was demonstrated.

\section{Discussion of the results obtained in the study of applicability of methods of fuzzy sets and classical mathematical analysis}

Simulation of choice of relative propeller axle rotation frequency ensuring spatial vehicle motion according to the transformed models [8] and by means of formation of membership functions for control actions according to the definitions 1-3 was performed. The results of choosing the propeller axle rotation speed at a coordinated pairwise motor actuation have demonstrated simplicity and stability of algorithms. Under conditions of choice of the $c \in[0,5,2]$ constant, practically decoupled motions are realizable. For example, the $\Theta$ angle is practically unlimited $\left(\Theta \in\left[30^{\circ}, 90^{\circ}\right]\right.$, Table 3) at a fixed $\Psi=35.312^{\circ}$.

Maximum speed of the vehicle, resolution and speed of the camera used for navigation form requirements to reduction of deviation of the $\Theta$ and $\Psi$ angles. As a result of calculations, it can be seen that the range of choosing the $c \in[0.5,2]$ constant can be narrowed to the interval of $c \in[0.71,1.41]$. At such reduction, the design constraints for the range of change the $\Theta$ and $\Psi$ angles become less tight (at $\Psi \in\left[32^{\circ}, 35^{\circ}\right]$ the angle $\left.\Theta \in\left[40^{\circ}, 71^{\circ}\right]\right)$. It is this narrowing that improves working conditions of the cameras and design requirements to technical and economic indicators. Obviously, the opportunity that opens due to simultaneous minimization of time and separation of control of mutually orthogonal motions is an advantage and a positive result of the study. Besides, it should be noted that analyticity of the operators with which the transformed intersection and combination operations are specified and the properties of the chain rule of differentiation determines differentiation of the result of its action.

It should be noted that realization of the mentioned advantages of the new list of operations is achieved only in conditions of construction of membership functions as the only analytical expressions satisfying condition of continuity and differentiation. The latter is the main problem of further studies.

At the same time, it is a major obstacle, since the problem of finding a single universal expression of the law within the entire range of definition approaching the set of value points and absolutely precisely passes through individual points is the problem of agreement. In fact, it is a question of necessity of agreement of contradictions that cannot be agreed because of their nature.

In addition, analyticity of the membership functions will make it possible to use additional fuzzy descriptions of not fully described objects which in turn will enable statement of the problem of coordination and synthesis of control actions in simulation of functioning of individual mobile cybersystem sections.

\section{Conclusions}

1. An algorithm of correcting parameters of an optimal path was constructed as a solution of the problem of minimum time. It establishes conditions ensuring separation of motions and limitation of operation of motor drives through introduction of the $(c \in[0.5,2])$ constant.

2 . The formed control actions (forces and moments) together with the nonlinear hydrodynamic model of the CUV and the system of new operations and definitions of the membership functions make it possible to implement fast-acting algorithms of choosing the propeller axle rotation speed in a control with a feedback video communication and narrowing the range of variation of the $\Theta$ and $\Psi$ angles by means of a two-fold narrowing of the range of choice of the $c$ constant ( $c \in[0.71,1.41]$ for modern navigation cameras).

3 . The proposed new forms of operation with fuzzy sets defined in the normalized space in the range of real numbers $[0,1]$ are analytic and admit the operations of classical mathematical analysis in conditions of analyticity of the introduced membership functions (definitions (4)-(7)) in the range of $[0,1]$.

\section{References}

1. Future trends, newest drone tech revealed at CES 2016. URL: https://www.directionsmag.com/article/1178

2. Drones in 2018: Thought Leaders Make Predictions. URL: https://dronelife.com/2018/01/02/drones-2018-thought-leaders-predict-new-trends/

3. Austin R. Unmanned Aircraft Systems: UAVS Design, Development and Deployment. Wiley, 2010. 372 p.

4. Aleksandrow M. N., Trunow A. N. Metody i srodky adaptacyjnego sterowania w technice glebokovodnej // Materialy V Konferencji: Projektowanie I Budowa Obiectow Oceanotechniki. Szczecin, 1989. P. 53-54

5. Blincov V. S. Privyaznye podvodnye sistemy. Kyiv: Naukova dumka, 1998. 231 p.

6. Razrabotka i ispytanie adaptivnogo podvodnogo robota / Yastrebov V. S., Garbuz E. I., Filatov A. M., Blincov V. S., Ivanishin B. P., Trunov A. N., Pavlov A. P. // Sbornik nauchnyh trudov instituta Okeanologii im. P. P. Shirshova AN SSSR. 1990. P. 98-112.

7. Trunov A. Criteria for the evaluation of model's error for a hybrid architecture DSS in the underwater technology ACS // Eastern-European Journal of Enterprise Technologies. 2016. Vol. 6, Issue 9 (84). P. 55-62. doi: https://doi.org/10.15587/17294061.2016 .85585 
8. Trunov A. Recurrent transformation of the dynamics model for autonomous underwater vehicle in the inertial coordinate system // Eastern-European Journal of Enterprise Technologies. 2017. Vol. 2, Issue 4 (86). P. 39-47. doi: https://doi.org/10.15587/ 1729-4061.2017.95783

9. Fradkov A. L. O primenenii kiberneticheskih metodov v fizike // UFN. 2005. Vol. 175, Issue 2. P. 113-138.

10. Hodakov V. E., Sokolova N. A., Kiriychuk D. L. O razviti osnov teorii koordinacii slozhnyh sistem // Problemy informatsiinykh tekhnolohiy. 2014. Issue 2. P. 12-21.

11. Petrov E. G., Kosenko N. V. Koordinacionnoe upravlenie (menedzhment) processami realizacii resheniy // Systemy obrobky informatsiyi. 2014. Issue 8. P. 160-163.

12. Trunov A. Realization of the paradigm of prescribed control of a nonlinear object as the problem on maximization of adequacy // Eastern-European Journal of Enterprise Technologies. 2016. Vol. 4, Issue 4 (82). P. 50-58. doi: https://doi.org/10.15587/ 1729-4061.2016.75674

13. Bellman R. E., Kalaba R. E. Quasilinearization and nonlinear boundary - value problems. American Elsiver Publishing Company, 1965. $206 \mathrm{p}$.

14. Lukomskiy Yu. A., Chugunov V. S. Sistemy upravleniya morskimi podvizhnymi ob'ektami. Leningrad: Sudostroenie, 1988. 272 p.

15. Ikonnikov I. B. Samohodnye neobitaemye podvodnye apparaty. Leningrad: Sudostroenie, 1986. 264 p.

16. Korol' Yu. M. Uravnenie dvizheniya teleupravlyaemyh podvodnyh apparatov // Zbirnyk naukovykh prats UDMTU. 2002. Issue 2. P. $16-25$.

17. Slizhevskiy N. B. Hodkost' i upravlyaemost' podvodnyh tekhnicheskih sredstv. Nikolaev, 1998. 148 p.

18. Zhuravska I., Kulakovska I., Musiyenko M. Development of a method for determining the area of operation of unmanned vehicles formation by using the graph theory // Eastern-European Journal of Enterprise Technologies. 2018. Vol. 2, Issue 3 (92). P. 4-12. doi: https://doi.org/10.15587/1729-4061.2018.128745

19. Stereo vision and laser odometry for autonomous helicopters in GPS-denied indoor environments / Achtelik M., Bachrach A., He R., Prentice S., Roy N. // Unmanned Systems Technology XI. 2009. doi: https://doi.org/10.1117/12.819082

20. Localization and stabilization of micro aerial vehicles based on visual features tracking / Chudoba J., Saska M., Baca T., Preucil L. // 2014 International Conference on Unmanned Aircraft Systems (ICUAS). 2014. doi: https://doi.org/10.1109/icuas.2014.6842304

21. Engel J., Sturm J., Cremers D. Camera-based navigation of a low-cost quadrocopter // 2012 IEEE/RSJ International Conference on Intelligent Robots and Systems. 2012. doi: https://doi.org/10.1109/iros.2012.6385458

22. Klein G., Murray D. Parallel Tracking and Mapping for Small AR Workspaces // 2007 6th IEEE and ACM International Symposium on Mixed and Augmented Reality. 2007. doi: https://doi.org/10.1109/ismar.2007.4538852

23. AR-Drone as a Platform for Robotic Research and Education / Krajník T., Vonásek V., Fišer D., Faigl J. // Communications in Computer and Information Science. 2011. P. 172-186. doi: https://doi.org/10.1007/978-3-642-21975-7_16

24. External localization system for mobile robotics / Krajnik T., Nitsche M., Faigl J., Duckett T., Mejail M., Preucil L. // 2013 16th International Conference on Advanced Robotics (ICAR). 2013. doi: https://doi.org/10.1109/icar.2013.6766520

25. Krejsa J., Vechet S. Infrared Beacons based Localization of Mobile Robot // Electronics and Electrical Engineering. 2012. Vol. 117, Issue 1. doi: https://doi.org/10.5755/j01.eee.117.1.1046

26. Nickels K., Hutchinson S. Estimating uncertainty in SSD-based feature tracking // Image and Vision Computing. 2002. Vol. 20 Issue 1. P. 47-58. doi: https://doi.org/10.1016/s0262-8856(01)00076-2

27. Stewénius H., Engels C., Nistér D. Recent developments on direct relative orientation // ISPRS Journal of Photogrammetry and Remote Sensing. 2006. Vol. 60, Issue 4. P. 284-294. doi: https://doi.org/10.1016/j.isprsjprs.2006.03.005

28. Trajković M., Hedley M. Fast corner detection // Image and Vision Computing. 1998. Vol. 16, Issue 2. P. 75-87. doi: https:// doi.org/10.1016/s0262-8856(97)00056-5

29. Welch G., Bishop G. An introduction to the kalman filter // In Annual Conference on Computer Graphics and Interactive Techniques. 1995.

30. Development of double median filter for optical navigation problems / Musiyenko M. P., Denysov O. O., Zhuravska I. M., Burlachenko I. S. // 2016 IEEE First International Conference on Data Stream Mining \& Processing (DSMP). 2016. doi: https:// doi.org/10.1109/dsmp.2016.7583535

31. Burlachenko I., Zhuravska I., Musiyenko M. Devising a method for the active coordination of video cameras in optical navigation based on the multi-agent approach // Eastern-European Journal of Enterprise Technologies. 2017. Vol. 1, Issue 9 (85). P. 17-25. doi: https://doi.org/10.15587/1729-4061.2017.90863

32. Fisun M., Smith W., Trunov A. The vector rotor as instrument of image segmentation for sensors of automated system of technological control // 2017 12th International Scientific and Technical Conference on Computer Sciences and Information Technologies (CSIT). 2017. doi: https://doi.org/10.1109/stc-csit.2017.8098828

33. Trunov A., Fisun M., Malcheniuk A. The processing of hyperspectral images as matrix algebra operations // 2018 14th International Conference on Advanced Trends in Radioelecrtronics, Telecommunications and Computer Engineering (TCSET). 2018. doi: https://doi.org/10.1109/tcset.2018.8336305

34. Zhuravska I. M. Ensuring a stable wireless communication in cyber-physical systems with moving objects // Technology audit and production reserves. 2016. Vol. 5, Issue 2 (31). P. 58-64. doi: https://doi.org/10.15587/2312-8372.2016.80784 
35. Hardware-oriented turbo-product codes decoder architecture / Krainyk Y., Perov V., Musiyenko M., Davydenko Y. // 2017 9th IEEE International Conference on Intelligent Data Acquisition and Advanced Computing Systems: Technology and Applications (IDAACS). doi: https://doi.org/10.1109/idaacs.2017.8095067

36. Fuzzy decision support systems in marine practice / Solesvik M., Kondratenko Y., Kondratenko G., Sidenko I., Kharchenko V., Boyarchuk A. // 2017 IEEE International Conference on Fuzzy Systems (FUZZ-IEEE). 2017. doi: https://doi.org/10.1109/ fuzz-ieee.2017.8015471

37. Gomolka Z., Dudek-Dyduch E., Kondratenko Y. P. From Homogeneous Network to Neural Nets with Fractional Derivative Mechanism // Lecture Notes in Computer Science. 2017. P. 52-63. doi: https://doi.org/10.1007/978-3-319-59063-9_5

38. Computerized system for remote level control with discrete self-testing / Kondratenko Y. P., Kozlov O. V., Topalov A. M., Gerasin O. S. // ICTERI-2017, CEUR Workshop Proceedings Open Access. 2017. Vol. 1844. P. 608-619. URL: http://ceur-ws.org/ Vol-1844/10000608.pdf

39. Neuro-fuzzy observers of clamping force for magnetically operated movers of mobile robots / Kondratenko Y. P., Joachim R., Kozlov O. V., Zaporozhets Y. M., Gerasin O. S. // Tekhnichna Elektrodynamika. 2017. Vol. 2017, Issue 5. P. 53-61. doi: https:// doi.org/10.15407/techned2017.05.053

40. Kondratenko Y. P., Kondratenko N. Y. Reduced library of the soft computing analytic models for arithmetic operations with asymmetrical fuzzy numbers // Soft Computing: Developments, Methods and Applications. New York, 2016. P. 1-38.

41. Siahaan A. P. U. Uncertainty Estimation of Drone Propellers Acceleration and Stability // International Journal of Engineering Development and Research. 2016. doi: https://doi.org/10.31227/osf.io/ghmns

42. Trunov A. Recurrent approximation as the tool for expansion of functions and modes of operation of neural network // Eastern-European Journal of Enterprise Technologies. 2016. Vol. 5, Issue 4 (83). P. 41-48. doi: https://doi.org/10.15587/1729-4061.2016.81298

43. Trunov A., Belikov A. Application of recurrent approximation to the synthesis of neural network for control of processes phototherapy // 2015 IEEE 8th International Conference on Intelligent Data Acquisition and Advanced Computing Systems: Technology and Applications (IDAACS). 2015. doi: https://doi.org/10.1109/idaacs.2015.7341389

44. Trunov A. Peculiarities of the interaction of electromagnetic waves with bio tissue and tool for early diagnosis, prevention and treatment // 2016 IEEE 36th International Conference on Electronics and Nanotechnology (ELNANO). 2016. doi: https://doi.org/ 10.1109/elnano.2016.7493041

45. Trunov A. Theoretical predicting the probability of electron detachment for radical of cell photo acceptor // 2017 IEEE 37th International Conference on Electronics and Nanotechnology (ELNANO). 2017. doi: https://doi.org/10.1109/elnano.2017.7939776

46. Trunov, A. Recurrent Approximation in the Tasks of the Neural Network Synthesis for the Control of Process of Phototherapy // Computer Systems Healthcare and Medicine. Denmark, 2017. P. 213-248.

47. Trunov A., Malcheniuk A. Recurrent network as a tool for calibration in automated systems and interactive simulators // Eastern-European Journal of Enterprise Technologies. 2018. Vol. 2, Issue 9 (92). P. 54-60. doi: https://doi.org/10.15587/ 1729-4061.2018.126498 